\title{
THE FIRST RECORD OF ASCARIDOIDEA EGGS DISCOVERED IN CROCODYLIFORMES HOSTS FROM THE UPPER CRETACEOUS OF BRAZIL
}

\author{
DANIEL FONTANA FERREIRA CARDIA, REINALDO J. BERTINI, \\ LUCILENE GRANUZZIO CAMOSSI \& LUIZ ANTONIO LETIZIO \\ Núcleo de Evolução e Paleobiologia de Vertebrados, Departamento de Geologia Aplicada, \\ Instituto de Geociências e Ciências Exatas, Universidade Estadual Paulista, UNESP, Campus Rio Claro. \\ Av. 24 A / 1515, 13506-900, Rio Claro, SP, Brazil. \\ danielcardia@hotmail.com,rbertini@rc.unesp.br,lucilenecamossi@gmail.com,lletizio@hotmail.com
}

\begin{abstract}
A paleoparasitological investigation was carried out on Crocodyliformes coprolites discovered in the Municipality of Santo Anastácio, in the southwestern region of the State of São Paulo. Individual samples were extracted from the surface and internal portion of each coprolite which revealed the presence of thick-shelled parasite eggs in three of them. The morphological characteristics of the specimens, i.e., rounded or oval shape, thick-shelled with mammillated surface, as well as their size, suggest that these eggs belong to the superfamily Ascaridoidea, which are gastrointestinal parasite nematodes of vertebrates, popularly known as "roundworms". This is the first record of Ascaridoidea eggs discovered in Crocodyliformes hosts from the Upper Cretaceous of Brazil.
\end{abstract}

Keywords: Crocodylomorpha, ascaridoids, parasites, coprolites, Bauru Group.

RESUMO - Uma investigação paleoparasitológica foi conduzida em coprólitos de Crocodyliformes recuperados no Município de Santo Anastácio, região sudoeste do Estado de São Paulo. Amostras individuais foram extraídas da superfície e porções internas de cada coprólito, as quais revelaram a presença de ovos de parasitos com casca grossa em três coprólitos. As características morfológicas dos espécimes, tais como formato redondo ou oval, casca espessa com superfície mamilonada, bem como seu tamanho, sugerem que estes ovos pertençam a superfamília Ascaridoidea, nematódeos parasitos gastrointestinais de vertebrados, popularmente conhecidos como "lombrigas". Este é o primeiro registro de ovos Ascaridoidea encontrado em hospedeiros Crocodyliformes do Cretáceo Superior do Brasil.

Palavras-chave: Crocodylomorpha, ascaridoides, parasitos, coprólitos, Grupo Bauru.

\section{INTRODUCTION}

The Bauru Group (Upper Cretaceous, Brazil) comprises geological units representing one of the most extensive continental sedimentary areas in South America, composed mainly of lacustrine deposits in the Araçatuba Formation, fluvial deposits predominantly in the Adamantina and Uberaba formations, and alluvial sedimentation in the Marilia Formation (Fernandes \& Coimbra, 2000; Oliveira \& Santucci, 2017). The Bauru Group covers most of the western region of the State of São Paulo (Figure 1), with a more extensive area corresponding to the Adamantina Formation. This formation, over the years, has proved to be a rich fossiliferous geological unit, with the discovery of a variety of vertebrate fossils such as fishes, lizards, testudines, crocodylomorphs, dinosaurs, and mammals (Bertini et al., 1993; Azevedo et al., 2000).
Coprolites are frequently found in the proximity of fossil skeletons (Souto, 2000, 2011; Oliveira \& Santucci, 2017). However, a few reports have been published about they (Oliveira \& Santucci, 2017), indicating that much still remains to be explored (Fugassa et al., 2008; Hugot et al., 2014; Silva et al., 2014).

Crocodyliformes is the most abundant clade among the vertebrates present in the Bauru Group, which contains more than ten different groups (Bertini et al., 1993). In Brazil, parasitological studies on the fossilized feces of these animals have yet to be undertaken. Two studies involving parasites in coprolites of Crocodylomorpha have been conducted elsewhere. The first study, in Florida, USA, focused on alligators from the Pleistocene/Holocene boundary, dating back to approximately 10,000 years ago; in this study, Trematoda and Trichuridae nematode eggs were 


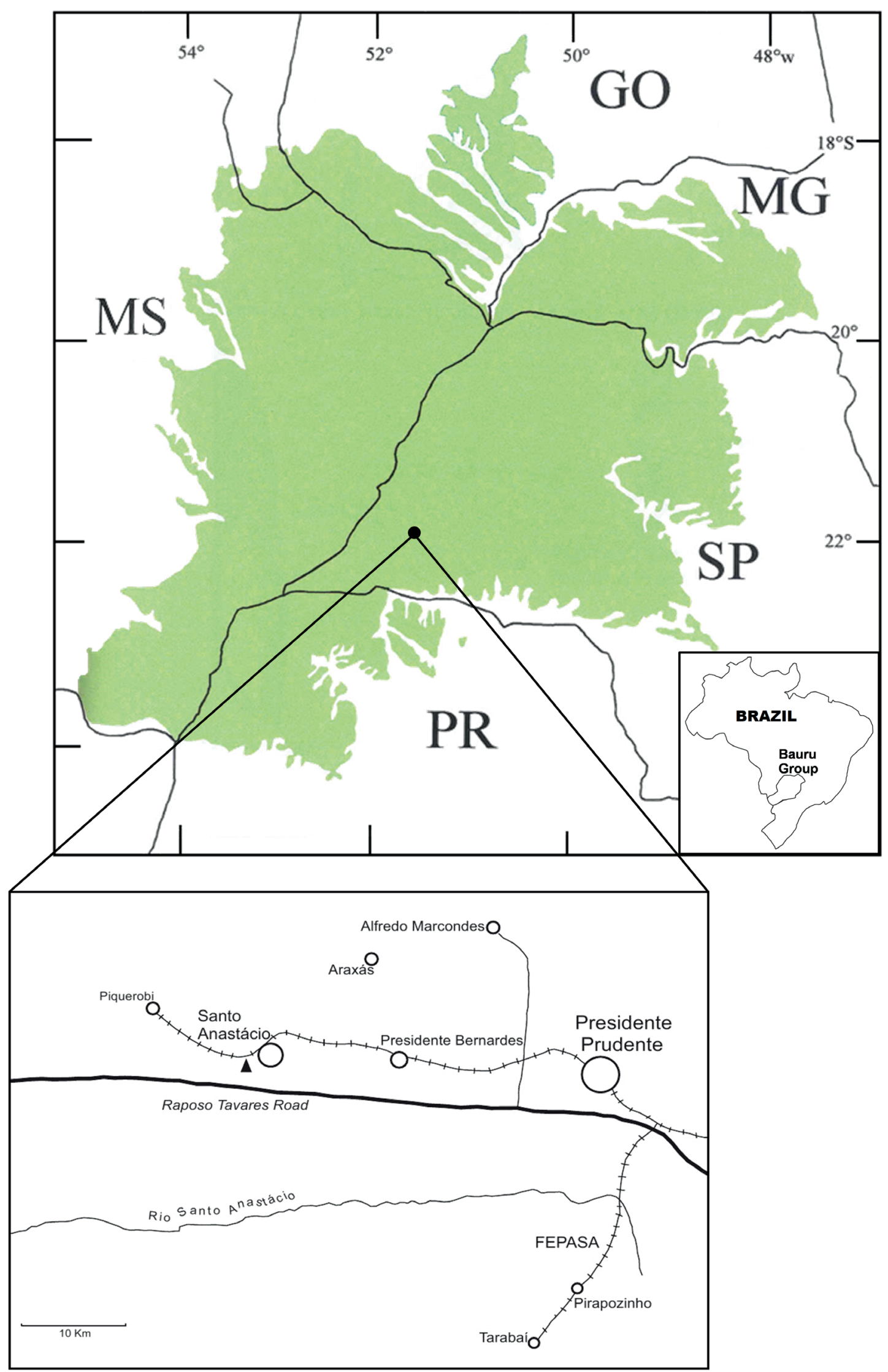

Figure 1. Geographical distribution of the Bauru Group through the states of Paraná (PR), Mato Grosso do Sul (MS), Goiás (GO), Minas Gerais (MG) and São Paulo (SP), showing the position of the site where the coprolites were discovered; Fossil locality ( $\mathbf{\Delta})$. 
found in 12 out of 28 coprolites (Reinhard et al., 1986). The second study describes an unidentified egg, possibly from a parasite, in one of 23 coprolites assigned to indeterminate crocodilians from the Urumaco Formation, Venezuela, from the Miocene, approximately 23-5 million years ago (Dentzien-Dias et al., 2018).

The paleoparasitological exploration of fossil feces enables researchers to identify parasite eggs or larvae, infer dietary habits, predator-prey relationships and environmental information (Wolff et al., 2009; Vajda et al., 2016). Depending on the parasite identified, it is possible to deduce feeding patterns of these animals, whether omnivorous, piscivorous, carnivorous or possibly herbivorous. It is also possible to correlate the parasite with the type of environment, aquatic, semi-aquatic or terrestrial, and the climate features required for the parasite's survival.

The number of relevant paleoparasitological studies has increased in the $21^{\text {st }}$ century, especially on coprolites of different groups of vertebrates in Brazil and other countries (Fugassa et al., 2008; Wood et al., 2013; Dentzien-Dias et al., 2013, 2018; Hugot et al., 2014; Francischini et al., 2017). Nevertheless, the literature contains only two records imputed to Ascaridoid eggs in coprolites: Ascaridoidea eggs in an Iguanodon coprolite from the Cretaceous of Belgium (Poinar \& Boucot, 2006), and a species of ascarid egg found in a herbivorous cynodont coprolite from the Triassic of the Santa Maria Formation, in the State of Rio Grande do Sul, Brazil (Silva et al., 2014).

The discovery of eggs of Ascaridoidea parasites in Crocodyliformes coprolites, related to the Upper Cretaceous series (Campanian-Maastrichtian), is reported here for the first time.

\section{MATERIAL AND METHODS}

\section{Coprolites}

The 53 coprolites (complete and fragmented) analyzed in this study were recovered in association with Crocodyliform bones from a paleontological site located in the municipality of Santo Anastácio, in the southwestern region of the State of São Paulo, in southeastern Brazil, at the coordinates $21^{\circ} 58^{\prime} 30.163$ ”'S, 5139'11.138”W (Figure 1). The site is chronologically assigned as Late Cretaceous (Bertini, 1993), lithologically represented by sandstones, siltstones, mudstones, and conglomerates of fluvio-lacustrine origin (Suarez, 2002) (Figure 2). The coprolites were stored in glass flasks and housed in the Paulo Milton Barbosa Landim Paleontology and Stratigraphy Museum at the São Paulo State University (UNESP) in the Municipality of Rio Claro, under Collection No. URC R. 148.

These ichnofossils preserved through phosphatization in general showed an average length of $1.3 \mathrm{~cm}$ (varying from 0.2 to 3.9), average diameter of $0.8 \mathrm{~cm}$ (varying from 0.1 to 2.4 ), average weight of 3.7 grams (ranging from
1.0 to 20.0), a round or cylindrical shape and rounded or pointed ends. This morphology and the absence of food remains, such as bone fragments, are typical characteristics of Crocodylomorpha coprolites, due to the efficacy of the digestive system of this archosaurs (Souto et al., 2010; Lucas et al., 2012; Milàn, 2012; Dentzien-Dias et al., 2018).

\section{Laboratory processing}

Morphometric measurements of each of the 53 coprolites were taken using a caliper ruler, and they were weighed individually on a digital balance.

Individual samples were extracted from the surface and internal portion of the 53 coprolites using an electric drill, as described by Silva et al. (2014), resulting in some macerated material. At paleoparasitological processing requires the use of samples consisting of approximately 1 gram of each coprolite, several of the coprolites were totally destroyed. The resulting product was stored in properly labeled Falcon $15 \mathrm{ml}$ polypropylene tubes.

A $10 \%$ hydrochloric acid solution was added to the tubes, as described by Ferreira et al. (2011). Upon dissociation of the minerals, the reaction was stopped by adding a double volume of distilled water.

The resulting solution was washed several times with distilled water, and then sifted through a 500 mesh $(25 \mu \mathrm{m})$ Tyler sieve, as described by Bouchet et al. (1999). The residual material from each sample retained on the sieve was washed again in distilled water. A drop of this material was then placed on a microscope slide, three drops of glycerin were added, and the slide was covered with a coverslip. The material was analyzed by bright field microscopy at 100x and 400x magnification. Each egg was measured individually using an ocular micrometer.

\section{RESULTS}

Of the 53 coprolites analyzed here, three samples revealed Ascaridoidea nematodes (Figure 3). These coprolites showed the following morphology: Coprolite 1 - fragmented, with an apparently rounded end, length: $1.6 \mathrm{~cm}$, diameter: 1.0 $\mathrm{cm}$, and weight: 4 grams. Coprolite 3 - fragmented, with cylindrical shape, without rounded or pointed ends, length: $1.8 \mathrm{~cm}$, diameter: $1.0 \mathrm{~cm}$, weight: 7 grams. Coprolite $42-$ complete, with cylindrical shape, one end pointed and the other slightly rounded, length: $1.4 \mathrm{~cm}$, diameter: $0.9 \mathrm{~cm}$, and weight: 4 grams.

These coprolites exhibited three different morphotypes of Ascaridoidea eggs (Table 1; Figures 4-5).

In addition to Ascaridoidea eggs, other inclusions were observed by optical microscopy in the coprolites, such as Acanthocephala eggs (Coprolite 1), Gymnosperm bisaccate pollen grains (Coprolites 3 and 42), and fungal microconidia (Coprolites 1 and 42). 


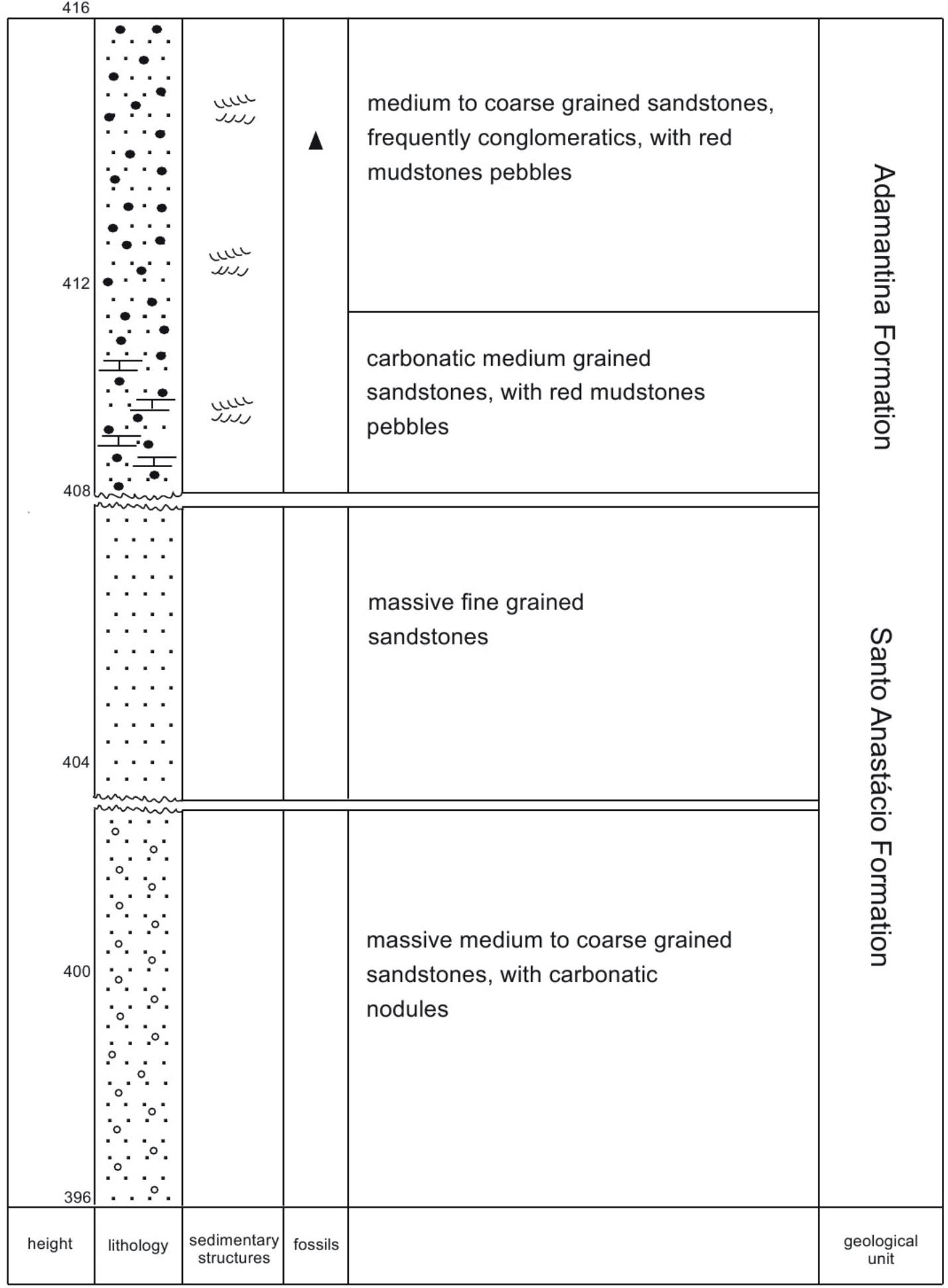

cross stratification

$\because \because$ massive sandstone

$\because \because$ sandstone with mudstone pebbles

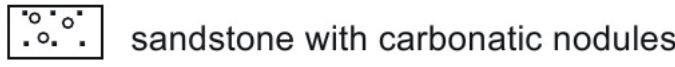

产. carbonatic sandstone

$\Delta$ fossils

Figure 2. Columnar section of the abandoned quarry on the outskirts of the Municipality of Santo Anastácio, southwestern State of São Paulo, Brazil. 

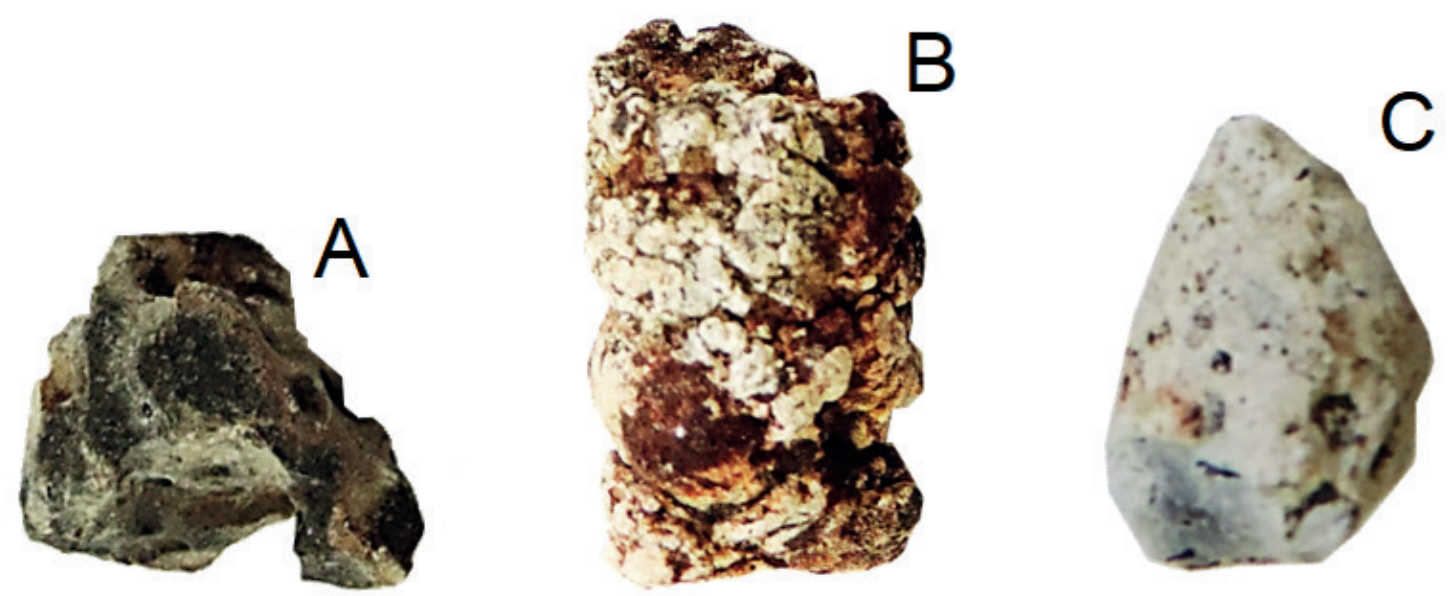

Figure 3. Coprolites with Ascaridoidea nematode eggs, from Crocodylomorpha hosts discovered in the municipality of Santo Anastácio, SP, Brazil. A, coprolite 1; $\mathbf{B}$, coprolite 3; C, coprolite 42. Scales bars $=10 \mathrm{~mm}$.

Table 1. Morphology and morphometry of the three different morphotypes of Ascaridoidea eggs discovered in coprolites from Crocodyliformes found in the Bauru Group (Upper Cretaceous). Morphotype I differs from Morphotype II in shape; Morphotype I differs from Morphotype III in size and degree of shell surface roughness; Morphotype II differs from Morphotype III in size and degree of shell surface roughness.

\begin{tabular}{|c|c|c|c|c|c|c|}
\hline Morphotype & Morphology & Length $(\mu \mathrm{m})$ & Width $(\mu \mathrm{m})$ & $\begin{array}{l}\text { Shell thickness } \\
\qquad(\mu \mathrm{m})\end{array}$ & Eggs & Coprolite \\
\hline I & $\begin{array}{l}\text { Oval, thick-shelled, highly mammillated surface } \\
\text { (rough, bumpy), uncleaved, apparently at one-cell } \\
\text { stage, inside the egg. }\end{array}$ & $57.5-67.5$ & $50-52.5$ & 5 & 2 & Coprolites 1 and 3 \\
\hline II & $\begin{array}{l}\text { Rounded, thick-shelled, highly mammillated surface } \\
\text { (rough, bumpy), uncleaved, apparently at one-cell } \\
\text { stage, inside the egg. }\end{array}$ & 60 & $50-55$ & $5-7.5$ & 2 & Coprolite 1 \\
\hline III & $\begin{array}{l}\text { Rounded, thick-shelled, slightly mammillated } \\
\text { surface (rough, bumpy), uncleaved, apparently at } \\
\text { one-cell stage, inside the egg. }\end{array}$ & 30 & 27.5 & 5 & 1 & Coprolite 42 \\
\hline
\end{tabular}

\section{DISCUSSION AND CONCLUSIONS}

Rounded or oval mammillated eggs are characteristic of the superfamily Ascaridoidea (Figures 4-5), and because of their morphological similarity, the eggs examined in this paleontological investigation were attributed to this nematode group. Parasites of this superfamily are commonly found in many modern crocodilians (Moravec, 2001; Tellez, 2013). Numerous genera of ascarids have been identified in modern crocodilians, including Brevimulticaecum, Dujardinascaris, Gedoelstascaris, Goezia, Hartwichia, Multicaecum, Ortleppascaris, Terranova, Trispiculascaris (Jacobson, 2007), indicating that this is a heterogeneous group of successful parasites in the evolutionary process, whose presence is found in crocodilian hosts from millions of years ago to the present day.

The ascarids found in modern crocodilians show morphological and morphometric similarities with those found in this investigation (Figures 4-5), indicating the possibility that these Crocodylomorpha acquired the parasitism through evolutionary heritage from their primitive ancestors. This finding may help researchers trace the evolution of parasites and their distribution throughout the world.

It is possible that this group of parasites, as well as other nematode parasites, emerged during the Cambrian/Ordovician period (Poinar, 2015). However, Ascaridoidea eggs had heretofore been described only in coprolites from the Triassic period (Silva et al., 2014). In correlation with the current species of ascaridoids of Crocodylomorpha, predatory habits can presumably explain how these parasites were acquired, suggesting that Crocodyliform hosts became parasitized by feeding on fishes and amphibians (Huchzermeyer, 2003). This paleoparasitological investigation revealed the abundant presence of ascaridoid parasites (Figures 4-5) in Crocodyliform coprolites during the CampanianMaastrichtian ages of Late Cretaceous (Figure 3) from the Adamantina Formation in the Bauru Group, in the southwestern region of the State of São Paulo. 


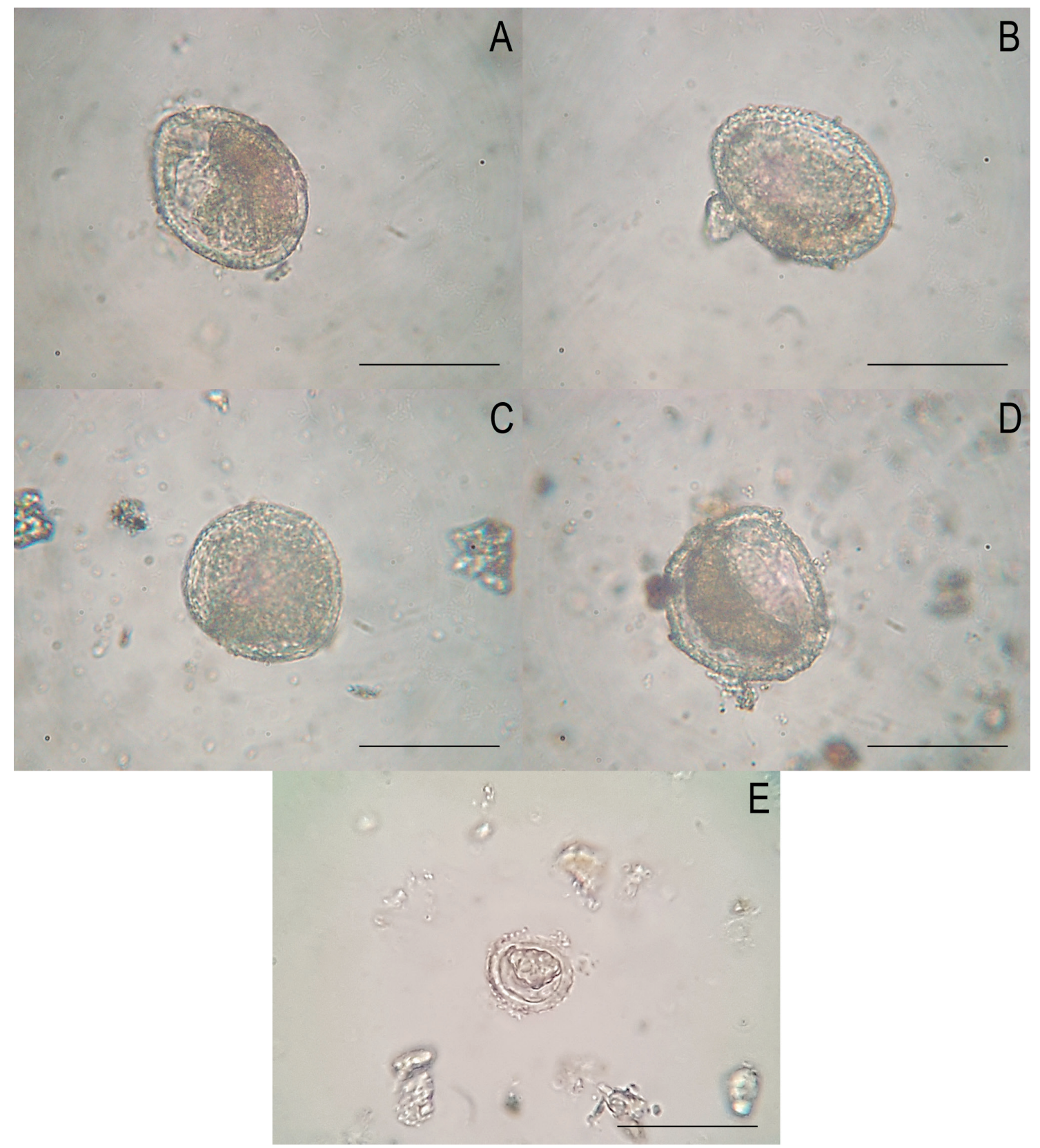

Figure 4. Photomicrographs of Ascaridoidea eggs found in Crocodyliform coprolites dating back to around 80-70 million years ago (400 x magnification). A-B, morphotype I; C-D, morphotype II; E, morphotype III. Scale bars $=50 \mu \mathrm{m}$.
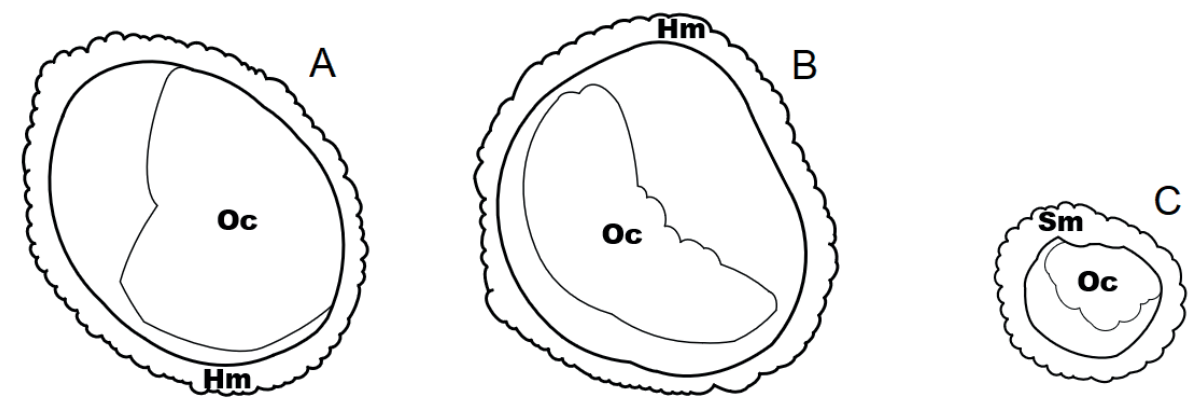

Figure 5. Representative drawings showing the morphology of the three different morphotypes of Ascaridoidea eggs found inside Crocodyliform coprolites dating back to about 80-70 million years ago. A, Morphotype I; B, Morphotype II; C, Morphotype III. Abbreviations: Hm, thick-shelled with highly mammillated surface; $\mathbf{S m}$, thick-shelled with slightly mammillated surface; $\mathbf{O c}$, one-cell stage. Scale bars $=50 \mu \mathrm{m}$. 


\section{ACKNOWLEDGMENTS}

The authors are grateful for all technical assistance provided by L.M. Dietrich Bertini. This research was not supported by any specific grant from research, a funding agency of the public, commercial, or not-for-profit sectors.

\section{REFERENCES}

Azevedo, S.A.; Gallo, V. \& Ferigolo, J. 2000. A possible chelonian egg from the Brazilian late cretaceous. Anais da Academia Brasileira de Ciências, 72:187-193. doi:10.1590/S000137652000000200007

Bertini, R.J. 1993. Paleobiologia do Grupo Bauru, Cretáceo Superior continental da Bacia do Paraná, com ênfase em sua fauna de amniotas. Programa de Pós-Graduação em Geologia, Universidade Federal do Rio de Janeiro, Tese de Doutoramento, $481 \mathrm{p}$.

Bertini, R.J.; Marshall, L.G.; Gayet, M. \& Brito, P.M. 1993. The vertebrate fauna from the Adamantina and Marilia formations, Upper Cretaceus of the Parana Basin, Southeast Brazil. Neues Jahrbuch fur Mineralogie, Geologie und Paleontologie, 188:72-101.

Bouchet, F.; Lefèvre, C.; West, D. \& Corbett, D. 1999. First paleoparasitological analysis of a midden in the Aleutian Islands (Alaska): results and limits. Journal of Parasitology, 85:369-372. doi:10.2307/3285649

Dentzien-Dias, P.; Carrillo-Briceño, J.D.; Francischini, H. \& Sánchez, R. 2018. Paleoecological and taphonomical aspects of the Late Miocene vertebrate coprolites (Urumaco Formation) of Venezuela. Palaeogeography, Palaeoclimatology, Palaeoecology, 490:590-603. doi:10.1016/j.palaeo.2017.11.048

Dentzien-Dias, P.C.; Poinar, G.; Figueiredo, A.E.Q.; Pacheco, A.C.L.; Horn, B.L.D. \& Schultz, C.L. 2013. Tapeworm eggs in a 270 million-year-old shark coprolite. PLoS One, 8:8-11. doi:10.1371/journal.pone.0055007

Fernandes, L.A. \& Coimbra, A.M. 2000. Revisão estratigráfica da parte oriental da Bacia Bauru (Neo-Cretáceo). Revista Brasileira de Geociências, 30:717-728.

Ferreira, L.F.; Reinhard, K.J. \& Araújo, A. 2011. Fundamentos da paleoparasitologia. $1^{\text {a }}$ ed. Rio de Janeiro, Editora FIOCRUZ, $484 \mathrm{p}$.

Fugassa, M.; Sardella, N.H.; Taglioretti, V.; Reinhard, K.J. \& Araújo, A. 2008. Eimeriid oocysts from archaeological samples in Patagonia, Argentina. Journal of Parasitology, 94:1418-1420. doi:10.1645/GE-1537.1

Francischini, H.; Dentzien-Dias, P. \& Schultz, C.L. 2017. A fresh look at ancient dungs: the Brazilian Triassic coprolites revisited. Lethaia, 51: 389-405. doi:10.1111/let.12251

Huchzermeyer, F.W. 2003. Crocodyles: Biology, Husbandry and Diseases. $1^{\mathrm{a}}$ ed. Cambridge, CABI Publishing, $352 \mathrm{p}$. doi:10.1079/9780851996561.0000

Hugot, J.P.; Gardner, S.L.; Borba Nunes, V.H.; Araújo, P.; Leles, D.; Stock Da-Rosa, A.A.; Dutra, J.M.F.; Ferreira, L.F. \& Araújo, A. 2014. Discovery of a 240 million year old nematode parasite egg in a cynodont coprolite sheds light on the early origin of pinworms in vertebrates. Parasit Vectors, 7:1-8. doi:10.1186/ s13071-014-0486-6

Jacobson, E.R. 2007. Infectious diseases and Pathology of reptiles: color atlas and text. $1^{\mathrm{a}}$ ed. Boca Ratton, CRC PRESS, 716 p.

Lucas, S.; Spielman, J.A.; Hunt, A.P. \& Emry, R.J. 2012. Crocodylian coprolites from the Eocene of the Zaysan Basin, Kazakstan.
New Mexico Museum of Natural History and Science, Bulletin, 57:319-322.

Milàn, J., 2012. Crocodylian scatology - a look into morphology, internal architecture, inter-and intraspecific variation and prey remains in extant crocodylian feces. New Mexico Museum of Natural History and Science Bulletin, 57:65-71.

Moravec, F. 2001. Some helminth parasites from Morelet's crocodile, Crocodylus moreletii, from Yucatan, Mexico. Folia Parasitologica, 48:47-62.

Oliveira, F.A. \& Santucci, R.M. 2017. Criteria for recognition and taphonomy of coprolites from the Serra da Galga Member, Marília Formation (Upper Cretaceous), Minas Gerais, Brazil. Journal of South American Earth Sciences, 78:1-16. doi:10.1016/j.jsames.2017.05.012

Poinar, G. \& Boucot, A.J. 2006. Evidence of intestinal parasite of dinosaurs. Parasitology, 133:245-249. doi:10.1017/ S0031182006000138

Poinar, G. 2015. The geological record of parasitic nematode evolution. Advances in Parasitology, 90:53-92. doi:10.1016/ bs.apar.2015.03.002

Reinhard, K.J.; Confalonieri, U.E.; Herrmann, B.; Ferreira, L.F. \& Araújo, A.J.G. 1986. Recovery of parasite remains from coprolites and latrines: aspects of paleoparasitological technique. Homo, 37:217-239.

Silva, P.A.; Borba Nunes, V.H.; Dutra, J.M.F.; Leles, D.; Stock Da-Rosa, A.A.; Ferreira, L.F. \& Araújo, A.A. 2014. New ascarid species in cynodont coprolite dated of 240 million years. Anais da Academia Brasileira de Ciências, 86:265-269. doi:10.1590/0001-3765201320130036

Souto, P.R.F. 2000. Tetrapode coprolites from the middle Triassic of southern Brazil. Gaia, Geoscience Journal, 16:51-57.

Souto, P.R.F. 2010. Crocodylomorph coprolites from the Bauru Basin, Upper Cretaceous, Brazil. New Mexico Museum of Natural History and Science, Bulletin, 51:201-208.

Souto, P.R.F. 2011. Estudo de micro inclusões em coprólitos. In: L.F. Ferreira, K. Reinhard \& A. Araújo (eds.) Fundamentos da Paleoparasitologia, Editora Fiocruz, p. 153-159.

Suarez, J.M. 2002. Sítio fossilífero de Pirapozinho, SP. Extraordinário depósito de quelônios do Cretáceo. In: C. Schobbenhaus; D.A. Campos; E.T Queiroz; M. Winge \& M.L.C. Berbert-Born (eds.) Sítios Geológicos e Paleontológicos do Brasil, DNPM / CPRM - Comissão Brasileira de Sítios Geológicos e Paleobiológicos (SIGEP), p. 49-54.

Tellez, M.A. 2013. Checklist of host-parasite interactions of the Order Crocodylia. $1^{\mathrm{a}}$ ed. Los Angeles, Univ. of California Publications in Zoology, 376 p.

Vajda, V.; Fernández, M.D.P.; Villanueva-Amadoz, U.; Lehsten, V. \& Alcalá, L. Dietary and environmental implications of Early Cretaceous predatory dinosaur coprolites from Teruel, Spain. Paleogeography, Paleoclimatology, Paleoecology, 464:134142. doi:10.1016/j.palaeo.2016.02.036

Wolff, E.D.S.; Slisbury, S.W.; Horner, J.R. \& Varricchio, D.J. 2009. Common avian infection plagued the tyrant dinosaurs. PLoS ONE, 4:e7288. doi:10.1371/journal.pone.0007288

Wood, J.R.; Wilmshurst, J.M.; Rawlence, N.J.; Bonner, K.I.; Worthy, T.H.; Kinsella, J.M. \& Cooper, A. 2013. A megafauna's microfauna: gastrointestinal parasites of New Zealand's extinct Moa (Aves: Dinornithiformes). PLoS One, 8:23-24. doi:10.1371/journal.pone.0057315

Received in 02 March, 2018; Accepted in 21 August, 2018. 